\title{
UNIVERSITY OF KIEL RADIOCARBON MEASUREMENTS II
}

\author{
H. WILLKOMM and H. ERLENKEUSER \\ $\mathrm{C}^{14}$ Laboratory of the University of Kiel, Germany
}

Most of the measurements reported here have been obtained with the 4.5- $\mathrm{L} \mathrm{CO}_{2}$ counter previously described (Kiel I; Erlenkeuser, 1965). A few samples have been dated with a 3-L proportional counter. The copper counter is surrounded by 28 GM counters in the form of a double ring. The total assembly is shielded by $10 \mathrm{~cm}$ of old lead. Neither an inner lead shield between counter and anticoincidence ring nor screening of sensitive volume by a quartz tube-as in the 4.5-L counter-has been used. Background of the small counter is $17.20 \mathrm{cpm}$ or $10.7 \frac{\mathrm{cpm}}{1000 \mathrm{~cm}^{2}}$. The $0.95 \mathrm{x}$ NBS value is $9.5 \mathrm{cpm}$ at 400 torr. Within statistical error background does not depend on atmospheric pressure. The 3-L counter is placed under a concrete wall, $2.5 \mathrm{~m}$ in length and $9.4 \mathrm{~m}$ in height.

In October, 1966 both equipments were placed under this wall with a common lead shielding containing four holes for low level counters. The general experimental arrangement of the apparatus was not changed except that the lead shielding above the two counters has been doubled to $20 \mathrm{~cm}$. The background of the 4.5-L counter dropped from $19.5 \mathrm{cpm}$ to $13.0 \mathrm{cpm}$ or $5.7 \frac{\mathrm{cpm}}{1000 \mathrm{~cm}^{2}}$. Meson flux has been reduced by a factor of 1.80 . Comparison of this reduction factor with the reduction of the total background shows that at least $5 \mathrm{cpm}$ are due to undetected mesons. Atmospheric pressure dependence of background has been reduced to about one half $\left(0.1 \frac{\mathrm{cpm}}{10 \text { torr }}\right.$ or $\left.0.7 \frac{\%}{10 \text { torr }}\right)$ of that of meson flux $\left(1.3 \frac{\%}{10 \text { torr }}\right)$ but has not vanished completely. We suppose this is due to gaps in the anticoincidence ring.

Background of the 3-L counter was reduced to $15.0 \mathrm{cpm}$ on account of doubling the shielding. We think the lower background of the longer counter to be caused by the inner lead shield and quartz tube screening.

Dates given are not corrected for $\mathrm{C}^{13} / \mathrm{C}^{12}$ ratio. Error quoted here corresponds to $1 \sigma$. No account has been taken of the error in the $\mathrm{C}^{1+}$ half-life and of the de Vries effect. Our dates are based on Libby halflife and A.D. 1950 as zero B.P.

\section{CHECK SAMPLES}

$126 \pm 60$

\section{KI-128. Oak-standard}

Sample described in Kiel I. Measured tree rings are from A.D. 1845 to 1850 and give an age-corrected activity of $94.74 \pm 0.8 \%$ of NBS standard. 


\section{Haltern series}

Charcoal of Roman main camp at Haltern $\left(51^{\circ} 44^{\prime} \mathrm{N}\right.$ Lat, $7^{\circ} 12^{\prime} \mathrm{E}$ Long), Germany. Subm. by Landesmuseum für Vor- und Frühgeschichte Münster, Germany. Charcoal is from wood burnt shortly before A.D. 9, when camp was abandoned (Beck, priv. commun.) (Münster, 1965; 1966).

\section{KI-68. Haltern 1965/1}

$$
1870 \pm 90
$$

Charcoal from lower part of cellar pit of camp barracks, $160 \mathrm{~cm}$ below surface; above water table. Coll. and subm. 1965 by K. Günther, Landesmuseum Münster.

\section{KI-75. Haltern 1962/2}

$$
1900 \pm 70
$$

Charcoal sand mixture from bottom of cistern, $130 \mathrm{~cm}$ below surface, above ground water level. Coll. 1962 by K. Günther; subm. 1966. Comment: averaging the two dates and using half-life of $5730 \mathrm{yr}$ an age of A.D. $10 \pm 55$ is obtained.

$$
\text { II. GEOLOGIC SAMPLES }
$$

\section{Nitrogen series, Dätgen}

The following two samples have been remeasured because of large statistical errors in earlier measurements (Kiel I). Ages given below are the weighted means of both measurements,

Peat samples D-N/1, D-N/2 from Grosses Moor at Dätgen $\left(54^{\circ}\right.$ 9.7' N Lat, 9० 55.7' E Long), Germany, are from upper and lower surfaces of a monolith used to estimate nitrogen content of light peat (Aletsee, 1967). Coll. 1961, subm. 1964 by L. Aletsee, Univ. of Kiel.

\section{KI-130. Dätgen D-N/1}

29 to $31 \mathrm{~cm}$ below surface.

\section{KI-131. Dätgen D-N/2}

121 to $123 \mathrm{~cm}$ below surface.
$1510 \pm 80$ A.D. 440

$$
2290 \pm 70
$$

\section{Dahldorf dates}

Dahldorf samples were coll. at $53^{\circ} 22.1^{\prime} \mathrm{N}$ Lat, $8^{\circ} 58.7^{\prime} \mathrm{E}$ Long. Subm. by F. Overbeck, Univ. of Kiel. Series contributes to investigation of younger history of settlement in northern Germany, and continues earlier measurements (Kiel I) on same subject.

\section{KI-25. Dahldorf II-5, $100 \mathrm{~cm}$ depth}

$3170 \pm 45$ 1220 B.C.

0 to $1 \mathrm{~cm}$ below contact between dark and light peat (depth of contact: $100 \mathrm{~cm}$ ), just below first indication of pollen of cereal type. Comment: numerous rootlets had to be removed before chemical treatment. Date includes result given in Kiel I. 
KI-138. Dahldorf II-7, $130 \mathrm{~cm}$ depth

$3510 \pm 65$

Maximum of Corylus (up to $38 \%$ ), Tilia less than $1 \%$, Plantago lanceolata in the beginning of a strong increase. Sample was mixed with small Euphorum rootlets removed before chemical treatment.

KI-140. Dahldorf II-9, $195 \mathrm{~cm}$ depth

$4600 \pm 100$

From this level upword continuous Plantago curve and Ulmus is below $5.2 \%$.

III. ARC.HEOLOGIC SAMPLES

\section{A.D. 1630}

$320 \pm 35$

KI-125. Gernsbach

Wood found in crypt of Evangelische Stadtkirche, Gernsbach $\left(48^{\circ}\right.$ $45^{\prime} \mathrm{N}$ Lat, $8^{\circ} 20^{\prime} \mathrm{E}$ Long), Germany. Subm. 1964 by U. Schaefer, now Univ. of Giessen.

KI-20. Gernsbach

$325 \pm 60$

Wood of coffin found in crypt of Evangelische Stadtkirche, Gernsbach, Germany. Subm. 1964 by U. of Schaefer. Date includes result given in Kiel I.

\section{KI-184. Gernsbach}

$275 \pm 70$

Bones of skeleton found in crypt of Evangelische Stadtkirche, Gernsbach. Subm. 1964 by U. Schaefer. Comment: according to de Vries effect (Suess, 1966; Stuiver, 1966) the true age of Gernsbach samples can only be predicted to lie between A.D. 1450 and 1650 .

$$
\mathbf{7 4 0} \pm \mathbf{5 0}
$$

\section{KI-71. Barmstedt}

A.D. 1210

Wood of well-preserved squared timber, in former times part of a structure which probably belonged to defense works of moated castle of Ritter von Barmstedt, Barmstedt ( $53^{\circ} 47^{\prime} \mathrm{N}$ Lat, 9० $46^{\prime} \mathrm{E}$ Long), Germany. Coll. 1963, subm. 1966 by A. Opfermann, Barmstedt. Timber and 20 roughly hewn piles were discovered at 3 to $4 \mathrm{~m}$ depth between the moat and an old pool, probably also part of defense works (Opfermann, priv. commun.).

\section{KI-78. Barmstedt}

$\mathbf{8 4 0} \pm \mathbf{7 0}$

Sample of one of the piles mentioned above. Pile showed ca. 40 rings only and is therefore a check against errors which arise from dating only the oldest parts of timber of this construction.

KI-180. Starnberger See

$4440 \pm 70$ 2490 B.c.

Peat from Allmannshauser Filze on eastern banks of Starnberger 
See (47 $54^{\prime} \mathrm{N}$ Lat, $11^{\circ} 20^{\prime}$ E Long). Germany. Coll. by Moorforschungsstelle Bernau, Germany; subm. 1965 by Schmeidl, Bernlau and F. R. Averdieck, Kiel Univ. Comment: Fagus 15\%, EMW 23\%, peat used for dating was located 3 to $5 \mathrm{~cm}$ below intersection of EMW $\mathrm{x}$ Fagus (Schmeidl, priv. commun.). Subject: study of settlement of southern Germany from Neolithic to Roman period.

\section{Chiemsee dates}

Wood from plankway in southern Chiemsee bogs $\left(47^{\circ} 48^{\prime} \mathrm{N}\right.$ Lat, $12^{\circ} 25^{\prime}$ E Long), Germany. Coll. 1965 by Schmeidl and Bernau; subm. 1965 by Schmeidl and F. R. Averdieck. The way has been dated by other methods to 600 B.c. (Schmeidl, priv. commun.).

\section{KI-181. Chiemsee-Moor}

$$
2580 \pm 60
$$

Picea $(5 \mathrm{~cm}$ diam), stem of

$$
630 \text { в.C. }
$$

lower of the two layers of the plankway.

\section{KI-182. Chiemsee-Moor}

$2540 \pm 80$

Alnus, stump of upper layer of the way.

\section{KI-69. Recke 1965/1}

590 B.c.

Charcoal, $70 \mathrm{~cm}$ below surface, at base of biggest of several barrows

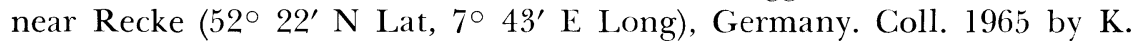
Günther, Landesmuseum für Vor-und Frühgeschichte, Münster, Germany; subm. 1965. No other artifacts have been found for dating this barrow (Münster, 1966).

\section{KI-152. Kiel-Ellerbek}

$5170 \pm 110$

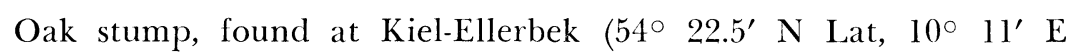
Long), Germany. Wood from final Mesolithic settlement, ca. $8.0 \mathrm{~m}$ below base peat. Subm. 1965 by F. R. Averdieck.

Date list:

\section{REFERENCES}

$$
\text { Kiel I Willkomm and Erlenkeuser, } 1966
$$

Aletsee, L., 1967, Begriffliche und floristische Grundlagen zu einer pflanzengeographischen Analyse der europäischen Regenwassermoorstandorte: Beiträge zur Biologie der Pflanzen, in press.

Erlenkeuser, H., 1965 Über eine Anlage zur Altersbestimmung $\mathrm{C}^{14}$-haltiger Substanzen: Diplomarbeit, Kiel.

Suess, H. E. 1965, Secular variations of the cosmic ray produced carbon ${ }^{14}$ in the atmosphere and their interpretations: Jour. Geophys. Res., v. 70, p. 5937-52.

Stuiver, M., and Suess, H. E., 1966, On the relationship between radiocarbon dates and true sample ages: Radiocarbon, v. 8, p. 534.

Münster, 1965, Landesmuseum für Vor- und Frühgeschichte und Altertumskommission für Westfalen: Neujahrsgruss 1965.

1966, Laudesmuseum für Vor- und Frühgeschichte und Altertumskommis sion für Westfalen: Neujahrsguss 1966. 